\title{
Origins of the Spanish Influenza pandemic (1918-1920) and its relation to the First World War
}

\author{
Anton Erkoreka \\ Basque Museum of the History of Medicine, Faculty of Medicine (UPV/EHU), E-48940 Leioa (Bizkaia), Spain \\ *Correspondence to: Anton Erkoreka, Email: a.erkoreka@ehu.es, Fax: +34946013211
}

Received 14 August 2009, Revised 01 November 2009, Accepted 05 November 2009, Published online 30 November 2009

J Mol Genet Med (2009), 3(2), 190-194

(C) Copyright The Author: This is an open access article, published under the terms of the Creative Commons Attribution Non-Commercial License (http://creativecommons.org/licenses/by-nc/2.0/uk/). This license permits noncommercial use, distribution and reproduction of the article, provided the original work is appropriately acknowledged with correct citation details.

\begin{abstract}
The virus which was responsible for the first benign wave of the Spanish Influenza in the spring of 1918, and which was to become extremely virulent by the end of the summer of 1918, was inextricably associated with the soldiers who fought during the First World War. The millions of young men who occupied the military camps and trenches were the substrate on which the influenza virus developed and expanded. Many factors contributed to it, such as: the mixing on French soil of soldiers and workers from the five continents, the very poor quality of life of the soldiers, agglomeration, stress, fear, war gasses used for the first time in history in a massive and indiscriminate manner, life exposed to the elements, cold weather, humidity and contact with birds, pigs and other animals, both wild and domestic. Today, this combination of circumstances is not present and so it seems unlikely that new pandemics, such as those associated with the avian influenza or swine influenza, will emerge with the virulence which characterized the Spanish Influenza during the autumn of 1918.
\end{abstract}

KEYWORDS: Pandemic influenza, Spanish influenza, Word War I, influenza A, H1N1

\section{INTRODUCTION}

The Spanish Influenza pandemic is one of the most lethal pandemics of the Modern Age. The number of deaths which it produced throughout the world has been estimated at 21.5 million (Jordan, 1927) and 39.3 million (Patterson and Pyle, 1991). Other researchers have proposed even higher figures, which seem to be somewhat excessive. Nevertheless, the appearance and development of the Spanish Influenza continue to present a number of unanswered questions (Phillips and Killingray, 2003; Gualde, 2006), which should be addressed in the light of the new influenza pandemics which have appeared at the beginning of the present XXI century, including the avian influenza and the swine influenza [A/swine (H1N1)], which are considered by some, such as Taubenberger et al
$(2005,2006)$ or Smith et al (2009), to be directly related to the Spanish Influenza.

The first pandemic wave, which was benign and caused few deaths, took place in the spring of 1918. After a period of calm at the beginning of the summer of 1918, the virus mutated, becoming extremely virulent, and simultaneously caused millions of deaths throughout the world during the following months of October and November. A milder third wave occurred during the initial months of 1919, while the fourth and final wave spread during the first months of 1920. The majority of those who died were young, healthy adults between the ages of 15 and 44 . Mortality rates varied between countries and continents, but mortality in Europe has been estimated to be $1.1 \%$ (Ansart et al, 2009) and 1.2\% (Erkoreka, 2006). 
Our principal concern here is to establish where, when and under what circumstances the pandemic began. Did it really begin in the Spring-Summer of 1918 or were there previous episodes related to the great pandemic, which constitute its prehistory?

\section{MATERIALS AND METHODS}

We examined the reports of the medical doctors who attended the French and American troops during the First World War. These documents are conserved in the Archives of the Health Services of the French Army (Archives du Service de Santé des Armées: ASSA), located in Val-de-Grâce (Paris). Other sources included medical articles and books published during that period. A variety of archives in France, Spain and Portugal were also consulted to provide more complete information.

\section{RESULTS AND DISCUSSION}

\section{The preceding pandemic of 1889-1890}

The 1889-1890 pandemic influenza is the most important antecedent and is particularly interesting due to its similarities and differences with respect to the later Spanish Influenza. It constitutes the link between the epidemics and pandemics which occurred in the Modern Age and the extremely virulent 1918 influenza. Between these pandemics, during the last decade of the XIX century and the first two decades of the XX century, multiple foci of influenza were reported in many places throughout the world. The doctors at that time attributed these foci to residues of the 1889-1890 pandemic and considered the influenza to be an endemic disease. At that time, seasonal influenza had not yet been distinguished from pandemic influenza and the underlying virus had not yet been discovered.

The 1889-1890 pandemic may have originated, among others, in the following countries: China (following the 1888 flooding); Athabasca in Canada (May 1889); Greenland (summer of 1889), Tomsk in Siberia or Bukhara in Uzbekistan (October 1889). We know with certainty that the first cases appeared in St. Petersburg (Russia) on $27^{\text {th }}$ October 1889, and expanded rapidly via railway to whole Europe. In Paris, the first cases were recorded on $17^{\text {th }}$ November; in Berlin and Vienna on $30^{\text {th }}$ November; in London around middle of December, and in southern European countries, from Italy to Portugal towards the end of December. The influenza spread overseas to America in January 1890, with the first cases appearing in Boston and New York. During the first months of the year, it spread throughout North and South America, Africa, Asia and Oceania, arriving by August to remote islands such as Madagascar, Jamaica and Santa Helena.

In Paris (Bertillon, 1892), the first cases were benign and affected, among others, employees of large commercial stores, and of the post and telegraph office services. From $15^{\text {th }}$ December onwards, the virus became extremely virulent and mortality rose steeply. The period of maximal viral effect took place between 16 December 1889 and 31 January 1890, when over 5,042 deaths were recorded in Paris. The majority of cases were older than 50 years of age; more men than women died and the number of miscarriages did not increase. The mortality rate was estimated to be 2.1 per 1000 people in the general population (men 2.5 per 1000; women 1.7 per 1000).

A medical report presented by Professor Proust to the Académie de Médecine identified three distinct forms in which the influenza presented itself, although these forms co-presented in the majority of cases:

i) Nervous influenza: Very brusque beginning, intense cephalalgia, intense pain in the eye orbits, joints and muscles. By the end of one to four days, these symptoms ceased and a strong dry cough appeared. This was accompanied, on occasion, by scarlatiniform, rubeoliform and skin rash on the anterior part of the arms, wrists and chest. On occasion, urticaria was observed.

ii) Pulmonary form: Similar to the latter, but with pharyngeal, laryngeal and pulmonary symptoms. This form of pulmonary congestion, chest angina and pneumonia was the most serious of all.

iii) Gastric form: Characterized by digestive disease, vomiting and diarrhea, etc.

\section{Étaples (1916-1917)}

Oxford et al $(2002,2005)$ have suggested that the beginnings of the pandemic occurred in the British military base at Étaples, situated in the north of France (Department of Pas-de-Calais). This military base, which was quite important throughout the First World War, was occupied by 100,000 soldiers within a space of $12 \mathrm{~km}^{2}$. The base was situated near sea marshes with abundant migratory birds. Nearby, there were many farms with pigs, ducks and geese reserved as food for the soldiers, and horses which were used as a means of transport.

The mixture of crowded soldiers, animals and 24 types of war gasses, which were massively used at the war fronts many of which were mutagenic - might have been the cause of the appearance of the first outbreak of the epidemic between December 1916 and March 1917. According to Oxford et al, "in the outbreak from December 1916 to March 1917, soldiers were admitted to the base hospitals, suffering from acute respiratory infection, high temperature, and cough at a time when recognised influenza was present. Clinical examination showed, in most cases, signs of bronchopneumonia, and pathology history showed acute purulent bronchitis. This outbreak was further clinically characterised by heliotrope cyanosis described extensively in the ensuing 1918 outbreak, and very high mortality". Hammond et al (1917) described this forgotten epidemic of purulent bronchitis, which Abrahams et al (1919) compared with the great pandemic of the Spanish Influenza: "We emphasize our view that in essential, the influenza pneumococcal purulent bronchitis that we and others described in 1916 and 1917 is fundamentally the same condition as the influenza pneumonia of this present 1918 pandemic".

\section{"Pneumonie des Annamites" (1916-1918)}

The Great War obliged France to mobilize hundreds of thousands of men. During the early years of the War, 
French colonies were scarcely involved, but as the War began to bleed France, army units were organized in the French colonies in Africa, Asia and Oceania. These units were known as "indigenous" units in the terminology of that era. Hundreds of thousands of troops were transported to French soil to fight at the fronts and collaborate in the rearguard.

Indochinese soldiers from the old Annam kingdom (presently Vietnam, Laos and Cambodia) fought on French soil between 1916 and 1918. Frémeaux (2006) has pointed out that over 50,000 Indochinese soldiers had been sent to France, half of whom were assigned to stage battalions (bataillons d'etapes). Over 9,000 Annamites served as nurses and 5,000 as car and lorry drivers. In the Archives of the Health Services of the French Army in Paris, we found many references to periodic epidemics, which affected these Indochinese soldiers between 1916 and 1918. These are referred to in the military medical reports as Annamite Pneumonia ("Pneumonie des Annamites"), and pneumococcus infections ("infections $\grave{a}$ pneumocoques"), among other terms.

A report signed by the military doctor Cachie on 13 May 1918 (Cachie, 1918) describes the epidemic, which began on the $30^{\text {th }}$ April among the Indochinese soldiers. The symptoms which he describes clearly indicate the presence of a complex influenza: "On 30 $0^{\text {th }}$ April, 23 indigenous soldiers presented to the medical (à la contrevisite) with morbid symptoms which had brusquely appeared a few hours earlier and which could be summarized as follows: $38-40^{\circ} \mathrm{C}$ fever, strong cough, occasionally accompanied by vomiting, cephalalgia, backache, generalized muscular pain.../... On the first of May, during the morning visit, 43 new cases of the same disease were observed in the same Unit.../... progressively worse cough, with expectoration which was sometimes bloody, but which upon examination, seemed to be of pharyngeal origin, rales of disseminated bronchitis in the two lungs, zones of congestive localization in the same organs..."

\section{New York (February, 1918)}

In the ASSA archives in Paris, we found another 1918 report by a medical doctor, Pic (Pic, 1918), in which he indicates that the influenza epidemic "began in February, in the USA, in the Sing-Sing Prison, in New York". More recently, other authors (e.g., Oslon et al, 2005) have found additional evidence for this New York influenza epidemic.

\section{Camp Funston (Kansas), (March, 1918)}

Fragmentary information from this period refers to distinct outbreaks of influenza in the USA and in other countries during the period 1915-1916. Barry (2005) and others mention an acute infectious outbreak among young farmers in a locality of Kansas called Haskell County. This occurred in February 1918 and, due to its clinical gravity, was compared to the Spanish Influenza. Many of these young farmers were called to arms and incorporated into the Funston military camp.

An article from that time (Vaughan, 1921) indicates that the epidemic began on $5^{\text {th }}$ March 1918 among the Chinese workers contracted at the Fort Riley military base in Funston (Kansas). Patterson and Pyle (1991) also refer to this influenza outbreak which affected 1,100 soldiers. Since that publication, it is generally accepted that the Spanish Influenza pandemic began at that time. However, we believe that it is problematic to assign such a specific date to the beginnings of the pandemic, since its origins are likely to be much more complex and varied.

\section{Villers-sur-Coudun (April, 1918)}

Among the abundant documentation which is conserved in the Paris ASSA archives, there is a "Note regarding influenza in the army from April to $10^{\text {th }}$ November of 1918" (Archives du Services de Santé des Armées, Paris, Carton 814; also see Figure 1), in which it is affirmed that the first cases of influenza appeared in the Third Army ( $3^{\circ}$ Armée) in Villers-sur-Coudun (Department of Oise) and in the Fère-Briange training field from the $10^{\text {th }}$ to the $20^{\text {th }}$ April (1918). Influenza broke out in the American army which was based on French soil towards the $15^{\text {th }}$ April (1918), in the outskirts of Bordeaux. It presented in the form of an epidemic of benign fever accompanied by cold-like symptoms; the American doctors considered that the underlying etiological agent was Pfeiffer's Bacillus (Emerson, 1918). Some sources from that time (Malheiro, 1921) also refer to cases of influenza in April in the $1^{\circ}$ and $2^{\circ}$ battalions of the British army in France, in the German army at the Western front and indicate that the first case of influenza was reported on $27^{\text {th }}$ April in Belgium, specifically in the Military Hospital of Cabour, situated in Adinkerke (Department of West-Vlaanderen).

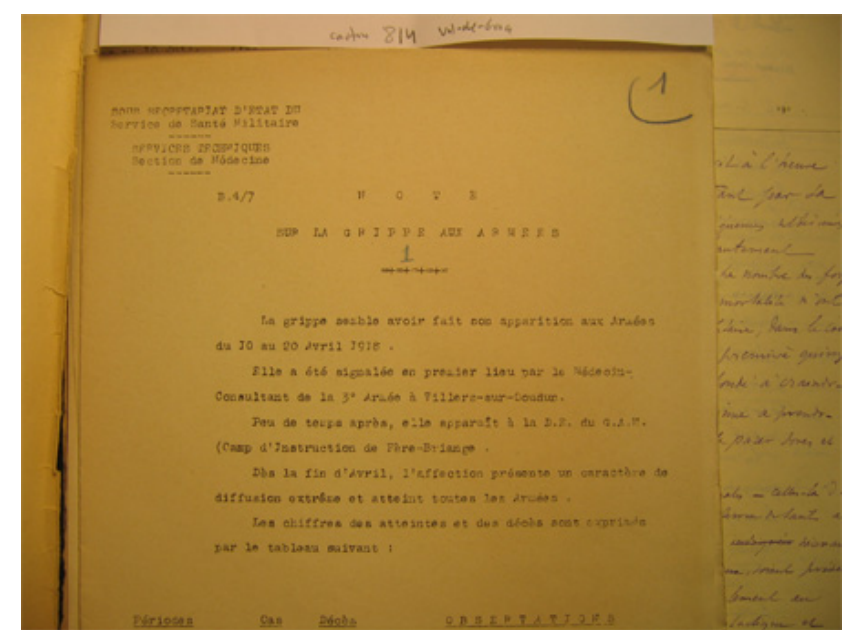

Figure 1. Original document reporting the start of the pandemic in the American and French Armies (Photographed by the author; courtesy ASSA, Box 814).

This first epidemic wave of the spring of 1918 was benign, affecting many soldiers but causing few deaths. In the French army, 24,886 influenza patients were recorded in May, with 7 deaths; 12,304 in June, with 24 deaths and 2,369 patients in July with 6 deaths, all of whom were diagnosed with "grippe" (influenza). Reports by the American army doctors indicate that there were 1,850 
cases of "influenza" in April, 1,124 in May, 5,700 in June and 5,788 in July. The first 5 American soldier victims of the influenza died during July.

\section{Madrid (May, 1918)}

The first country in Western Europe in which the pandemic was widespread among the general population and caused significant mortality, was Spain. It justifies the denomination "Spanish Influenza" used to refer to this pandemic. The first reference in the Spanish press to an epidemic outbreak in the spring of 1918 can be found in the Madrid newspaper "El Sol", which published its first headline about the subject on 22 May 1918. The report goes as follows: "it seems that many cases are appearing among the soldiers of the Madrid garrison of a sickness which has not yet been diagnosed by doctors. Among an artillery regiment, 80 soldiers have been affected by this disease. In other regiments, the number ascends to up to 50 similar cases. .../... Undoubtedly, there is little difference between the disease observed in the prisons by our reporters and that which has been affecting Madrid for the last few days. .../... The symptoms associated with the disease are headache, shivering, weakness, fever and joint pains, and the condition sometimes presents itself at thoracic or intestinal levels".

During the months of May and June (1918), there were 276 influenza deaths in Madrid (Boletín de la Estadística Municipal de Madrid), which represents a mortality rate of 0.42 per 1000 inhabitants. During the same period, another 852 deaths occurred of patients who had been diagnosed with different pathologies of the respiratory system. If deaths due to influenza are combined with those due all other pathologies of the respiratory system, we obtain a mortality rate of 1.31 per 1000 inhabitants, which would be the highest mortality estimate attributable to this epidemic outbreak. This focus extended to the centre and West of the Iberian Peninsula, affecting Portugal in June, but not crossing the Pyrenees mountain range which separates Spain from France.

\section{Maritime transport, Tanger, Cádiz, Boston (1918)}

Malhiero (1921) suggested that the Spanish influenza was exported by boat to the USA from Tanger and the Spanish colonies in the north of Africa. He also cites the article by JJ Kaegan (Journal of the American Association, 28 November 1918) in which it is claimed that the disease was brought from Cadiz (Spain) to Boston by infected passengers, and subsequently disseminated rapidly throughout the entire country.

The Asian origin of the Spanish influenza has only meagerly been considered in the many books and papers, which have been written about this pandemic. Nevertheless, this hypothesis should not be lightly ruled out since links between the Spanish influenza and Asia can be established in terms of the Chinese workers at Camp Funston and the Indochinese soldiers of the French army affected by the Annamite Pneumonia. Thus, the spectacular virulence of the autumn 1918 epidemic wave could well have been contributed to by the recombination in Europe of viruses of Chinese and Indochinese origin.
Outbreak of mutated virus at the French-Spanish border (September, 1918)

Spain was a neutral country during the Great War, but it did permit the passage of Portuguese troops, workers and merchandise towards France, especially across its borders at Irun and Hendaia. This important communications hub between Paris and Madrid is situated in the Basque Country, at the outlet of the Bidasoa River, a marsh zone with abundant migratory birds. This frontier region could have been one of the places in which the virus mutated in Europe, becoming extremely virulent and invasive.

Upon examining the death certificates in Irun and Hendaia, we found that the first death with an influenza diagnosis occurred on 10 September 1918; within a month, $1 \%$ of its population died of influenza itself and respiratory and digestive complications. From October onwards, the pandemic affected nearby cities such as Biarritz, Vitoria-Gasteiz or more distant cities such as Bordeaux, Paris, Lyon, Rome, Barcelona, Alicante or Madrid. Between October and November, the pandemic had spread to the Balearic Islands, Switzerland and Germany. By November, the Spanish Influenza pandemic had spread to the Straits of Gibraltar, Algeria, Great Britain, Ireland and other European countries (Erkoreka, 2008, 2009).

\section{CONCLUSIONS}

The first wave of the epidemic in the spring of 1918 was a seasonal and benign influenza epidemic, similar to those which occur almost every year and caused little mortality. If there had only been this one epidemic wave, it would not have been of much historical interest and would not have motivated so much investigation.

The main conclusion of the present research into the origins and beginning of the Spanish Influenza pandemic is that it appears to be inextricably linked to the soldiers who fought during the First World War. The millions of young men in army barracks, military camps and trenches constituted the vulnerable substrate on which the influenza virus developed, became extremely virulent and spread worldwide in October and November (1918). These men came from almost every country all over the world as soldiers and workers from Europe, America, Asia, Africa and Oceania, who mixed on French soil. The causal factors included the poor quality living conditions of the soldiers, the agglomeration, stress, fear, war gasses used for the first time in history in a massive and indiscriminate manner, life exposed to the elements, the harsh cold with especially harsh winters, such as that of 1916; rain, snow and direct contact with birds, pigs and other animals, both wild and domestic.

Nowadays, the combination of these circumstances is evidently not present, making it unlikely that new influenza pandemics, such as those associated with the present day avian influenza or swine influenza $[\mathrm{A} / \mathrm{swine}$ (H1N1)], will exhibit the extension and virulence which characterized the Spanish Influenza in the autumn of 1918, 
which caused the death of between $1 \%$ and $2 \%$ of the world population. After all, the Spanish influenza could be considered to be a "historic accident", another cruel consequence of the terrible First World War.

\section{ACKNOWLEDGEMENTS}

The authors would like to express their thanks to the Director, Xavier Tabbagh, and Staff of the Archives of the Health Services of the French Army (Paris) and to both Begoña Madarieta and Aitor Anduaga of the Basque Museum of the History of Medicine (Bilbao).

\section{COMPETING INTERESTS}

None declared.

\section{REFERENCES}

Abrahams A, Hallows N, French H. 1919. A Further Investigation into Influenza Pneumococcal and Influenza Streptococcal Septicaemia: Epidemic Influenza Pneumonia of Highly Fatal Type and its Relation to Purulent Bronchitis. Lancet, 1, 1-9.

Ansart S, Pelat C, Boelle PY et al. 2009. Mortality Burden of the 1918-1919 Influenza Pandemic in Europe. Influenza Other Respiratory Viruses, 3, 99-106.

Barry JM. 2005. The Great Influenza. The Story of the Deadliest Pandemic in History. New York, Penguin Books.

Bertillon J. 1892. La grippe a Paris et dans quelques autres villes de France et de l'étranger en 1889-1890. Annuaire Statistique de la ville de Paris pour l'année 1890, 97-131.

Cachie. 1918. "Le Medecin-Major $1^{\mathrm{a}}$ xl. Dr. Cachie. Rapport du Médecin chargé du Service Médical du Centre d'Instruction Automobile Indo-Chinois sur une epidémie survenue fin Avril 1918", Archive du Service de Santé des Armées, Paris, Carton 810. Emerson H. 1918. Sous Secretariat d'Etat du Service de Santé Militaire. Services Techniques. Section Franco-Américaine. Haven EMERSON a Monsieur le Médecin Major de 1ère classe RAYNAUD. Mission Française - TOURS. "La grippe dans l'Armée Américaine" (circa sep.1918), Archive du Service de Santé des Armées, Paris, Carton 813.

Erkoreka A. 2006. La pandemia de gripe española en el País Vasco (1918-1919). Bilbao, MHM.
Erkoreka A. 2008. Spanish Influenza in the Heart of Europe. A Study of a Significant Sample of the Basque Population. Gesnerus. Swiss J Hist Med Sci, 65, 30-41.

Erkoreka A. 2009. The Spanish Influenza Pandemic in Occidental Europe (1918-1920) and Victim Age. (Submitted)

Frémeaux J. 2006. Les colonies dans la Grand Guerre. Combats et épreuves des peuples d'Outre-mer. Cahors, 14-18 éditions.

Gualde N. 2006. Comprendre les épidémies. La coévolution des microbes et des hommes. Paris, Les Empêcheurs de penser en rond. Hammond JAR, Rolland W and Shore THG. 1917. Purulent Bronchitis: a Study of Cases Occurring amongst the British Troops at a Base in France. Lancet, 2, 41-45.

Jordan EO. 1927. Epidemic Influenza: A Survey. Chicago, American Medical Association.

Malheiro AH. 1921. A gripe. Estudo de epidemiologia. Porto, Facultade de Medicina.

Olson DR, Simonsen L, Edelson PJ et al. 2005. Epidemiological Evidence of an Early Wave of the 1918 Influenza Pandemic in New York City. Proc Natl Acad Sci USA, 102, 11059-11063.

Oxford JS, Sefton A, Innes W et al. 2002. World War I may have Allowed the Emergence of Spanish Influenza. Lancet Infect Dis, 2, 111-114.

Oxford JS, Lambkin R, Sefton A et al. 2005. A Hyphotesis: the Conjunction of Soldiers, Gas, Pigs, Ducks, Geese and Horses in Northern France During the Great War Provided the Conditions for the Emergence of the "Spanish" Influenza Pandemic of 1918-1919. Vaccine, 23, 940-945.

Patterson KD and Pyle GF. 1991. The Geography and Mortality of the 1918-1919 Influenza Pandemic. Bull Hist Med, 65, 4-21.

Phillips H and Killingray D (Ed). 2003. The Spanish Influenza Pandemic of 1918-1919, New Perspectives, London, Routledge.

Pic A. 1918. "Le Médecin-Major de I classe A Pic, Adjoint Technique au Directeur du Service de Santé de la $14^{\circ}$ Région, à M. le Sous-Secretaire d'Etat du Service de Sante Militaire... le 15 Novembre 1918”. Archives du Service de Santé des Armées, Paris, Carton 813.

Smith GJD, Bahl J, Dhanasekaran V et al. 2009. Dating the Emergence of Pandemic Viruses. Proc Natl Acad Sci USA, 106, 11709-11712.

Taubenberger JK, Reid AH, Lourens RM et al. 2005. Characterization of the 1918 Influenza Virus Polymerase Genes. Nature, 437, 889-893.

Taubenberger JK, Morens DM. 2006. 1918 influenza: the Mother of all Pandemics. Emerg Infect Dis, 12, 15-22.

Vaughan WT. 1921. Influenza: An Epidemiologic Study. Baltimore. 